\title{
Atmospheric controls on mineral dust emission from the Bodélé Depression, Chad: The role of the low level jet
}

\author{
Richard Washington ${ }^{1}$ and Martin C. Todd ${ }^{2}$ \\ Received 23 May 2005; revised 8 July 2005; accepted 27 July 2005; published 3 September 2005.
}

[1] Atmospheric aerosols play an important though uncertain role in the Earth's climate system. The Bodélé Depression in Chad stands out as the planet's largest source of dust, yet very little is known about the atmospheric circulation that maintain this source. We investigate what key large-scale features of the circulation over the Bodélé account for its primacy as a mineral aerosol source. We show, for the first time, the structure and characteristics of the Bodélé Low Level Jet (LLJ) which has a maximum speed near $18^{\circ} \mathrm{N}, 19^{\circ} \mathrm{E}$ at $925 \mathrm{hPa}$. It is strongest in the northern winter, receding with the advance of summer in phase with dustiness in the Bodélé. Variability of dust over the Bodélé occurs contemporaneously with the ridging of the Libyan High and pulsing of the pressure gradient which drives the northeasterlies in which the LLJ is embedded. Citation: Washington, R., and M. C. Todd (2005), Atmospheric controls on mineral dust emission from the Bodélé Depression, Chad: The role of the low level jet, Geophys. Res. Lett., 32, L17701, doi:10.1029/2005GL023597.

\section{Introduction}

[2] Atmospheric aerosols influence the Earth's radiation budget and are, therefore, an important component of the Earth's climate system, and likely play an important role in global climate change [Kaufman et al., 2002]. Aerosols are one of the greatest sources of uncertainty in the interpretation and projection of past and future climate change [Ramaswamy et al., 2001]. In many regions, mineral dust is the biggest contribution to atmospheric optical thickness [Tegen et al., 1997], and evidence exists of increasing dust production in recent decades [Goudie and Middleton, 1992; Prospero and Lamb, 2003].

[3] TOMS (Total Ozone Mapping Spectrometer) Aerosol Index (AI) data [Herman et al., 1997] highlights the importance of the old deserts, particularly in North Africa and the Middle East, as key mineral aerosol sources [Prospero et al., 2002; Washington et al., 2003]. Using TOMS AI data, Washington et al. [2003] determine the key source region within North Africa to be 1) the Bodélé Depression in Chad, 2) the Djouf region spanning the northern border of Mali and Mauritania (Figure 1), and 3) the Chotts of eastern Algeria and Tunisia and a broad region of central Libya. This is consistent with the idea

\footnotetext{
${ }^{1}$ Climatology Research Group, Oxford University Centre for the Environment, University of Oxford, UK.

${ }^{2}$ Department of Geography, University College London, London, UK.
}

Copyright 2005 by the American Geophysical Union. 0094-8276/05/2005GL023597 that the world's entrained mineral dust is associated with a small number of key preferential source regions [Ginoux et al., 2001; Prospero et al., 2002]. According to TOMS AI long term means, by far the most important of the African sources is the Bodélé Depression, in northern Chad an area of some $40000 \mathrm{~km}^{2}$ centered on $16^{\circ} \mathrm{N}$ and $18^{\circ} \mathrm{E}$, which, unlike almost all other dust sources, remains a major dust source throughout the year [Washington et al., 2003]. The primacy of the Bodélé has also emerged in other satellite-derived data, e.g. the Infrared Dust Differencing Index (IDDI) [Brooks and Legrand, 2000], Multi-angle Imaging Spectroradiometer (MISR) [Zhang and Christopher, 2003] and MODIS (MODerate resolution Imaging Spectroradiometer) [Koren and Kaufman, 2004].

[4] The entrainment of large quantities of dust into the atmosphere require two sets of conditions, namely a supply of surface sediment (erodibility) and strong surface winds (erosivity). The Bodélé is a very large source of diatomite palaeo lake sediment associated with Mega-Lake Chad. Hyper aridity (estimated annual average rainfall $<10 \mathrm{~mm}$ [New et al., 2002]), the accompanying absence of vegetation, in combination with very fine material, most likely ensures extreme erodibility. But strong surface winds are also essential to any explanation of the Bodélé's global prominence as a dust source. With the exception of Koren and Kaufman [2004], who developed a novel method to constrain rates of dust plume transport from the Bodélé using MODIS imagery, very little is known about how the atmospheric circulation generates the necessary erosivity to ensure that the Bodélé is such an important source of mineral aerosols.

[5] Accordingly, this paper answers the following key questions:

[6] 1. What key features of the circulation over the Bodélé account for its primacy as a mineral aerosol source?

[7] 2. Can intraseasonal to interannual variability of mineral aerosol production from the Bodélé be explained by variability in these atmospheric features?

[8] Since mineral aerosol production is known to vary from year to year [Washington et al., 2003] while also increasing on secular time scales [Prospero and Lamb, 2003], an important contribution to our understanding of aerosols would emerge if such variability could be traced to the associated modulation of the atmospheric circulation as against, for example, purely anthropogenic modification of the land surface.

[9] In the course of answering these questions, we show, for the first time, the existence of a Low Level Jet (LLJ) which overlies the Bodélé Depression in West Africa. We go on to demonstrate that variability in dust production on both intraseasonal and interannual time 


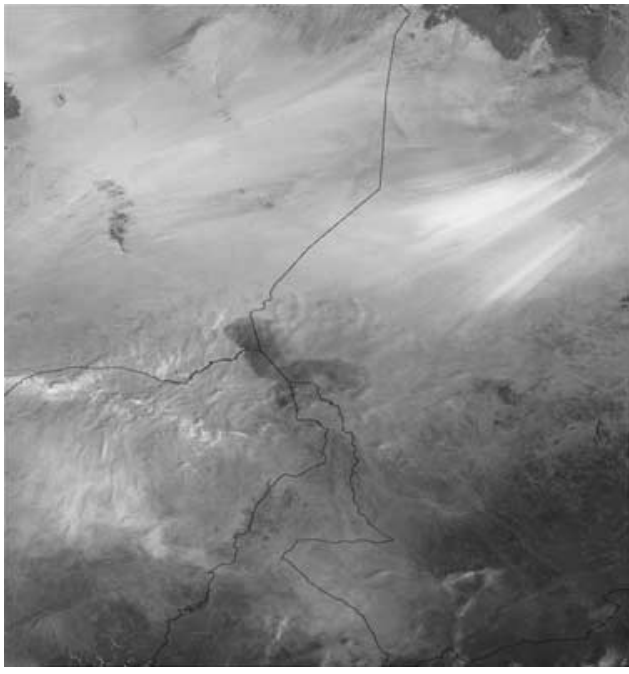

Figure 1. Example of dust plume from Bodélé Depression (3 March 2003) as observed from MODIS. See color version of this figure in the HTML.

scales is associated with the modulation of the strength and size of the LLJ.

\section{Data}

[10] Information on atmospheric dust over the Bodélé region is derived from (i) monthly mean TOMS aerosol optical thickness (AOT) products on a 1-degree grid [Torres et al., 2002] (ii) daily TOMS AI from the Nimbus-7 satellite on a $1.25 \times 1$ degree grid [Herman et al., 1997]. We use data only from the Nimbus-7 TOMS sensor from 1979-92 (iii) MODIS Level 1B channel 4, 3, 1 images from 20022004 from which a subjectively derived climatology of dust plume frequency over the Bodélé was derived. Information on the large-scale atmospheric circulation is obtained from two independent reanalysis datasets: (i) The European Centre for Medium Range Weather Forecasts (ECMWF) ERA-40 dataset, providing monthly fields on a 1-degree grid (ii) National Center for Environmental Prediction

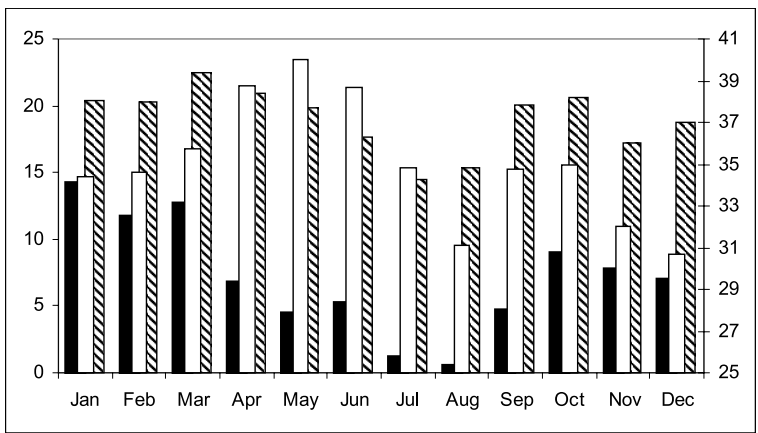

Figure 2. Monthly mean values for satellite derived estimates of dust over the Bodélé Depression, TOMS AOT (hatched) (1979-1992), monthly mean frequency of large dust plumes over the Bodélé (2002-2004) (black), TOMS AI $(\times 10),(1979-1992)$ (white) using right hand vertical axis. a

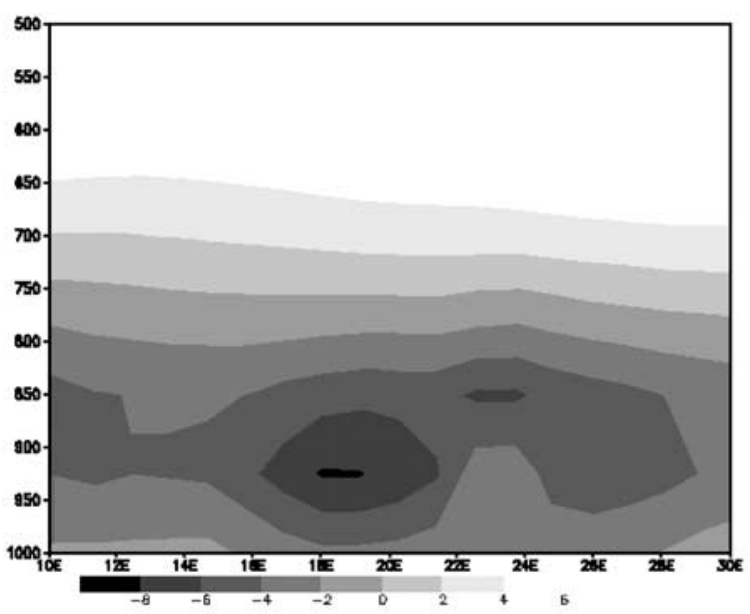

b

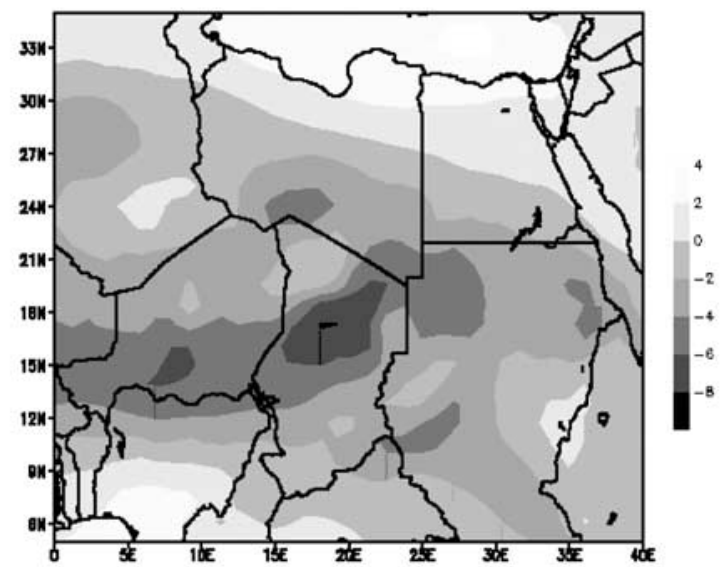

Figure 3. Mean (1979-1992) ERA-40 zonal winds $\left(\mathrm{m} . \mathrm{s}^{-1}\right)$ in Bodele region during January to April (a) longitude-height section along $18^{\circ} \mathrm{N}$ (location of Bodélé Depression) between $10^{\circ} \mathrm{E}$ and $30^{\circ} \mathrm{E}$ (b) at $925 \mathrm{hPa}$.

(NCEP) reanalysis dataset [Kalnay et al., 1996], providing daily fields on a 2.5 degree grid.

\section{The Bodélé Low Level Jet (LLJ): Climatology}

[11] The large scale structure of the wind in the Sahel and central Sahara, although complicated, has been well described, at least for the Boreal summer months of the monsoon [Cook, 1999]. Much less has been written about the wind structure in the months of the rest of the year, outside the monsoon season, but during which there is considerable dust activity, particularly in the Bodélé.

[12] Both the TOMS AI and AOT products highlight the Bodélé as having the highest mean annual values globally [Washington et al., 2003; Zhang and Christopher, 2003]. The long term mean (1979-1992) annual cycle of TOMS AOT from this region shows high values throughout the year but with a semi-annual cycle with a primary peak in March, a secondary peak in October and minimum in August (Figure 2). TOMS AI data (Figure 2) (1979-1992) shows high levels of dust throughout the year, with a peak in May and a minimum in August. It is known that TOMS AI is 


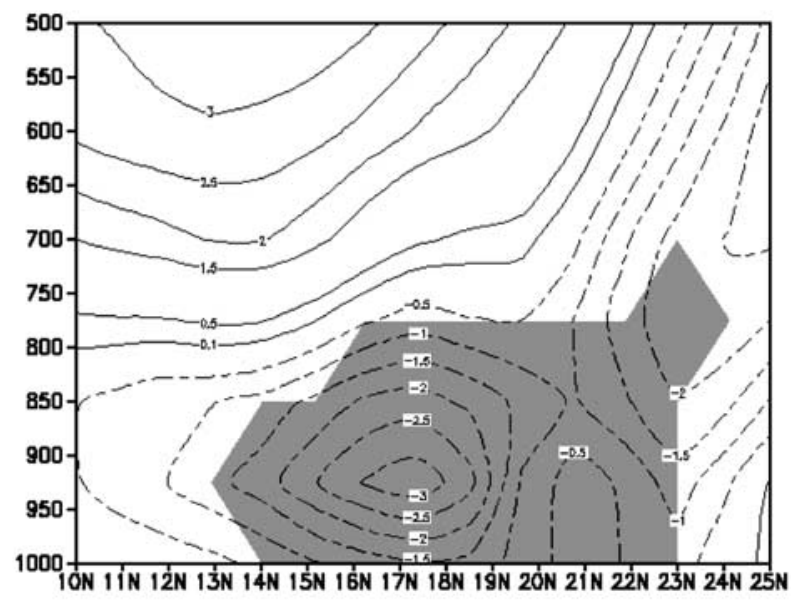

Figure 4. Latitude-height section of mean ERA-40 zonal wind $\left(\mathrm{m} . \mathrm{s}^{-1}\right)$ composite difference anomalies along $18^{\circ} \mathrm{E}$ for a sample of 8 high minus 8 low dust months during January-April 1979-92. Contours $0.5 \mathrm{~m} . \mathrm{s}^{-1}$,shading shows significant differences at 0.05 level.

sensitive to the height of the dust layer, underestimating dust at heights less than $1.5 \mathrm{~km}$ [Herman et al., 1997]. Large scale subsidence is likely to ensure that dust transport occurs in the lowest layers during winter whereas deep, dry convection during summer may lift dust to at least midtropospheric heights [Mahowald and Dufresne, 2004]. This is a likely explanation for the phase shift in the annual cycle of the TOMS AI data towards the summer months, compared with the TOMS AOT, as this is when the boundary layer beings to deepen considerably. The TOMS AOT data is in broad agreement with dust plume climatology over the Bodélé which shows nearly twice as many dust plumes in January to March as in other months of the year (Figure 2). Accordingly, in this paper we use the months of January to April as indicative of enhanced dustiness.

[13] A key feature of the ERA-40 (1979-1992) mean circulation data in the Bodélé Depression region (in all seasons except summer) is a low level easterly wind maximum of $-8 \mathrm{~m} \cdot \mathrm{s}^{-1}$ at about $900 \mathrm{hPa}$ near $18^{\circ} \mathrm{N}$ and $19^{\circ} \mathrm{E}$ (Figure 3a). This LLJ maximum coincides with the exit gap of the North-easterlies between the Tibesti mountains and the Ennedi massif which lie $2600 \mathrm{~m}$ and $1000 \mathrm{~m}$ above the flat terrain in the Djourab Desert of Chad respectively. The effect of the Tibesti massif is clearly evident in creating a 'split' in the low-level easterly flow north and south of the mountains (Figure 3b). While the LLJ feature is pronounced over the Bodélé, it is absent from other longitudes over west Africa along $18^{\circ} \mathrm{N}$. It is therefore a feature which uniquely overlies the greater Bodélé region, downwind of the mountains of Chad. The LLJ undergoes a marked seasonal cycle, partly in phase with the dustiness over the Bodélé, and is active in the October-March period and relatively inactive $\left(<3 \mathrm{~m} . \mathrm{s}^{-1}\right)$ from June-August (not shown).

\section{Variability in Dust From the Bodélé Depression and the LLJ}

[14] The previous section shows the co-location of a LLJ feature with a maximum in dust loadings over the Bodélé.
That the LLJ is closely associated with dust production can be strengthened by evaluating the characteristics of the LLJ in months of extreme dust production from the Bodélé. If the location of the LLJ over the Bodélé was simply coincidental, then we would not expect the LLJ to increase (decrease) during high (low) dust months.

[15] From the TOMS AOT record for the Bodélé Depression, we pick the two most dusty and least dusty January, February, March and April months for the period 1979-1992, yielding 8 high and 8 low dust sampling months. Composite zonal wind anomalies were calculated from ERA-40 data based on these samples of high minus low TOMS AOT months. Results indicate a strengthening of the LLJ by about $3 \mathrm{~ms}^{-1}$ over the Bodélé during the high dust months relative to the low dust months, representing a deviation of about $40 \%$ relative to the mean LLJ zonal velocity (Figure 4). The LLJ strength is significantly modulated during extremes in dust production sampled on

a
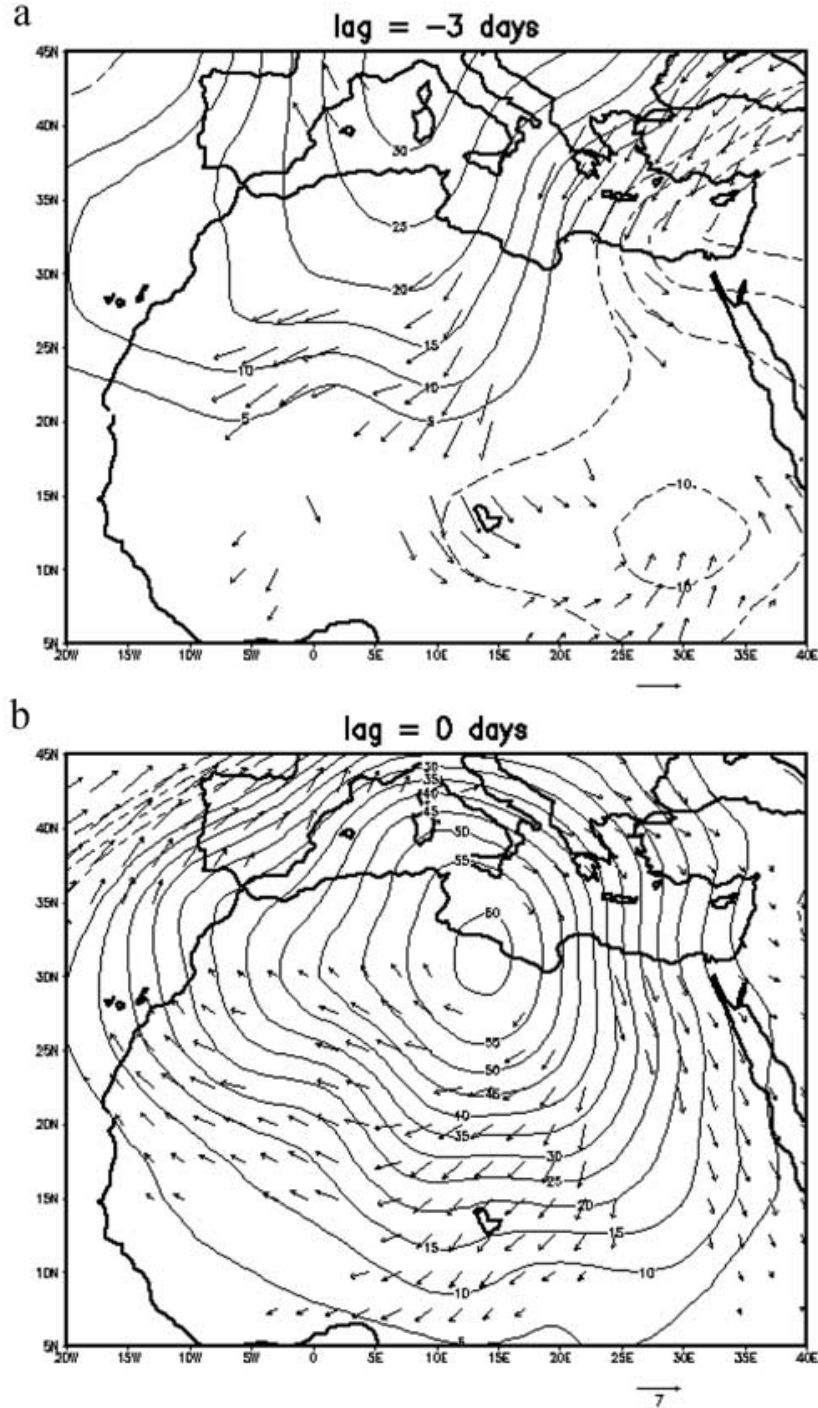

Figure 5. $1000 \mathrm{hPa}$ Geopotential height anomalies (contours $5 \mathrm{gpm}$ ) and $925 \mathrm{hPa}$ winds (vectors) associated with a +2 standard deviation in TOMS AI $\left(16.5^{\circ} \mathrm{N}, 16.5^{\circ} \mathrm{E}\right)$ for a) -3 day lag, b) zero lag. Only wind vectors and contours significant at the 0.05 level are shown. 
an interannual basis and therefore, on these timescales, the LLJ is closely associated with dust production.

[16] Next, we show that the LLJ is modulated, in phase with dust variability, on intra-seasonal timescales, the causes of which we trace to the evolution of a specific synoptic system. To do this, we regress daily gridded January to April NCEP $925 \mathrm{hPa}$ geopotential height and winds onto a bandpass filtered time series of daily January to April TOMS AI values for the Bodélé (TOMS AOT are not available on daily timescales). We have used daily NCEP fields because we do not have access to daily ERA-40 data. First, the seasonal cycle was removed from the daily Bodélé TOMS AI timeseries by subtracting the 30 -day running mean of the long term daily mean TOMS AI values over Bodélé. Second, this timeseries of daily TOMS AI anomalies was bandpass filtered to retain variability in the broad 10-35 day band, a procedure common to analysis of intra-seasonal variability. This filter bandwidth is justified by spectral peaks in the Bodélé TOMS AI anomaly timeseries near 12, 20 and 25 days based on three spectral techniques (Lomb periodogram, Blackman-Tukey and multi-taper) of independent 120 day series for January to April throughout the available TOMS AI record (variability at timescales $<10$ days cannot be quantified due to aliasing of artefacts in the TOMS AI record associated with satellite orbital characteristics). The bandpass filtered daily Bodélé AI timeseries for January to April 1979-92 is then regressed against the daily NCEP fields at each grid box within a broad North African domain for the same period. Using the resulting regression equations at each grid box, the linear dependence of the NCEP variable on bandpassed Bodélé AI can be derived, based on an arbitrary deviation of Bodélé AI (in this case +2 standard deviations). The local significance ( 0.05 level) of the regression slope is assessed. Regressions are derived at lags of -15 to +15 days and are used to map the evolution of the circulation over time (following Kiladis and Weickmann [1992]).

[17] Intra-seasonal variability in dust over the Bodélé region is associated with variability in the intensity of the Libyan high pressure system (Figure 5). Positive Bodélé AI anomalies are associated with significant positive $925 \mathrm{mb}$ height anomalies which grow from about day $=-3$ over the western Mediterranean region (Figure 5a), propagate southeast to be centred over northern Libya at day $=0$ (Figure 5b), before declining and moving eastwards. High dust production therefore results from the significantly strengthened north easterlies and easterlies flowing around an intensified Libyan high and is one mechanism by which the LLJ is pulsed.

\section{Discussion and Conclusion}

[18] The Bodélé Depression is known to be an important source of mineral aerosols. Its prominence in the Sahara must arise because of both the erodibility of the surface material and the erosivity of the wind. In this paper we have drawn attention to the Bodélé Low Level Jet, a feature which is most active in the dusty months of the year. In the ERA-40 data, the jet has a core at $925 \mathrm{hPa}$ near $18^{\circ} \mathrm{N}, 20^{\circ} \mathrm{E}$ and is present in all months of the year except August although it is strongest in January and weakest in July.
Typical reanalysis speeds in the jet core are $-8 \mathrm{~m} \cdot \mathrm{s}^{-1}$. Koren and Kaufman [2004] have shown that the reanalyses data (NCEP) underestimates the windspeeds in this key region by up to $50 \%$. A wind of $16 \mathrm{~m} . \mathrm{s}^{-1}$ is of jet strength. The jet is absent along $18^{\circ} \mathrm{N}$ over the rest of west Africa where the topography is largely flat, suggesting that it is probably topographic channelling between the Tibesti and the Ennedi Massif that locally accelerates the wind.

[19] Sampling based on extreme dust years shows that interannual variability is associated with a strengthening of the LLJ during dusty years and a retraction of the jet during years with extremely low dust loadings. Intraseasonal variability of dust over the Bodélé occurs contemporaneously with the ridging of the Libyan High and pulsing of the pressure gradient which drives the northeasterlies in which the LLJ is embedded.

[20] This paper has shown that the mesoscale features in the atmospheric circulation have a key role to play in the generation and transport of mineral aerosols. It remains to be seen whether the large variability in year to year and decade to decade loadings of dust in the atmosphere [e.g., Prospero and Lamb, 2003] hinge on the atmospheric circulation or whether they arise mainly from anthropogenic changes to factors such as surface erodibility.

[21] Acknowledgment. Thanks to Fiona Mitchell, CRG, OUCE, who analysed MODIS images.

\section{References}

Brooks, N., and M. Legrand (2000), Dust variability over northern Africa and rainfall in the Sahel, in Linking Climate Change to Land Surface Change, edited by S. McLaren and D. Kniveton, pp. 1-25, Springer, New York.

Cook, K. H. (1999), Generation of the African Easterly Jet and its role in determining West African precipitation, J. Clim., 12, 1166-1184.

Ginoux, P., M. Chin, I. Tegen, J. Prospero, B. Holben, O. Dubovik, and S. J. Lin (2001), Sources and distributions of dust aerosols simulated with the GOCART model, J. Geophys. Res., 106(D17), 20,255-20,273.

Goudie, A. S., and N. J. Middleton (1992), The changing frequency of dust storms through time, Clim. Change, 20, 197-225.

Herman, J. R., P. K. Bhartia, O. Torres, C. Hsu, C. Seftor, and E. Celarier (1997), Global distribution of UV-absorbing aerosols from Nimbus 7/Toms data, J. Geophys. Res., 102(D14), 16,911-16,922.

Kalnay, E., et al. (1996), The NCEP/NCAR 40-year reanalysis project, Bull. Am. Meteorol. Soc., 77, 437-471.

Kaufman, Y. J., D. Tanre, and O. Boucher (2002), A satellite view of aerosols in the climate system, Nature, 419, 215-223.

Kiladis, G. N., and K. M. Weickmann (1992), Circulation anomalies associated with tropical convection during northern winter, Mon. Weather Rev., 120(9), 1900-1923.

Koren, I., and Y. J. Kaufman (2004), Direct wind measurements of Saharan dust events from Terra and Aqua satellites, Geophys. Res. Lett., 31, L06122, doi:10.1029/2003GL019338.

Mahowald, N. M., and J. L. Dufresne (2004), Sensitivity of TOMS aerosol index to boundary layer height: Implications for detection of mineral aerosol sources, Geophys. Res. Lett., 31, L03103, doi:10.1029/ 2003GL018865.

New, M. G., D. Lister, M. Hulme, and I. Makin (2002), A high-resolution data set of surface climate for terrestrial land areas, Clim. Res., 21, $1-25$.

Prospero, J. M., and P. J. Lamb (2003), African droughts and dust transport to the Caribbean: Climate change implications, Science, 302(5647), $1024-1027$.

Prospero, J. M., P. Ginoux, O. Torres, S. E. Nicholson, and T. E. Gill (2002), Environmental characterization of global sources of atmospheric soil dust identified with the Nimbus 7 Total Ozone Mapping Spectrometer (TOMS) absorbing aerosol product, Rev. Geophys., 40(1), 1002, doi:10.1029/2000RG000095.

Ramaswamy, V., O. Boucher, J. Haigh, D. Hauglustaine, J. Haywood, G. Myhre, T. Nakajima, G. Y. Shi, and S. Solomon (2001), Radiative forcing of climate change, in Climate Change 2001: The Scientific Basis, pp. 349-416, Cambridge Univ. Press, New York. 
Tegen, I., P. Hollrig, M. Chin, I. Fung, D. Jacob, and J. Penner (1997), Contribution of different aerosol species to the global aerosol extinction optical thickness: Estimates from model results, J. Geophys. Res., 102(D20), 23,895-23,915

Torres, O., P. K. Bhartia, J. R. Herman, A. Sinyuk, and B. Holben (2002), A long term record of aerosol optical thickness from TOMS observations and comparison to AERONET measurements, J. Atmos. Sci., 59, $398-413$.

Washington, R. W., M. C. Todd, N. Middleton, and A. S. Goudie (2003), Dust-storm source areas determined by the total ozone monitoring spectrometer and surface observations, Ann. Assoc. Am. Geogr., 93, $297-313$.
Zhang, J., and S. A. Christopher (2003), Longwave radiative forcing of Saharan dust aerosols estimated from MODIS, MISR, and CERES observations on Terra, Geophys. Res. Lett., 30(23), 2188, doi:10.1029/ 2003GL018479

M. C. Todd, Department of Geography, University College London, 26 Bedford Way, London WC1E 6BT, UK. (m.todd@geog.ucl.ac.uk) R. Washington, Climatology Research Group, Oxford University Centre for the Environment, University of Oxford, Oxford OX1 3QY, UK. (richard.washington@ouce.ox.ac.uk) 